Проф. др Јован Делић

Универзитет у Београду

Филолошки факултет

821.163.41-32.09 Тартаља И.
https://doi.org/10.18485/ai_san_o_gradu.2018.ch27

\title{
САН О ГРАДУ И ГРАД СНОВА
}

Маргиналије уз књигу Ива Тартаље:

Беоіраg ХХІ века.

Из стиарих уйойија и анйиуйойија, СКЗ, 1989.

Наслов овога записа је двоструки криптоцитат: он је, прво, пастиш Тартаљиног наслова једног поглавља из необичне и драгоцјене књиге Беоіраg XXI

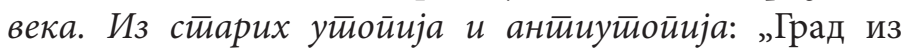
маште и град маштања“, али је и цитат поетског записа Иве Андрића „Сан о Граду“, хибридног текста, који би се, можда, могао називати путописним есејем или есејистичким путописом. Овај спој је - послије двију изузетних Тартаљиних књига о Андрићу: Прийовеgачева естиеииика (1979) и Пуй йореg знакова (1992, 2006²) - за нас природан, поготову када покушавамо да назначимо цјеловитост Тартаљиног опуса и да уочимо везе између веома далеких и разнородних књига.

Алузија на Андрићев „Сан о Граду“ има овдје још једно покриће: овај Андрићев запис о љепоти Дубровника Тартаља је цитирао као један од најзначајнијих за Андрићеву поетику, односно приповједачеву естетику. У њему се откривају нека темељна Андрићева поетичка начела, па и најзначајнији симболи. То је, прво, клесани камен, и то још, смислено слаїан. У Дубровнику су то „масе клесана и смислено слагана камена што се зову Минчмета, Ловријенац, Св. Влахо“. Из тих грађевина зрачи „мирна снага, власт над самим собом и страст за стварањем“. 
Љепотом градње и клесаним, смислено сложеним каменом, човјек се супроставио морској стихији и суровом копну - безумном мору, с једне, и глувом кршу, с друге стране - остваривши се „у најлепшој људској жељи да се крати живот радом и смислом сублимира и овековечи“.

У дубровачким зидовима Андрић види мудрост и обраћа им се у вокативу, као мудрацима од којих је научио велику тајну како се човјек може супроставити свом људском непознатом удесу:

Мудри дубровачки зидови, видим да је рад једино што човек може да супростави свом непознатом удесу.“

А само који редак раније Андрић је клесаном камену додао још рађену земъу и иессано gрво:

„Како је чудно и увек благотворно осећање што га имам кад гледам клесан камен, рађену земљу и тесано дрво. Видим да је лепота и целисходност сваког облика искупљења жртвом: paga и йоgврїавана законима. Зато је све што је створено у прошлости живо и непороменљиво у садашњости, јер је откупљено и плаћено, а дужина века му се мери по величини жртве којом је откупљено.“ (подвукао И. А.)

Рад, подвргавање законима стварања и жртва чине свето тројство стварања којим се човјек опире пролазности и захваљујући којем оплемењена и остварена прошлост, попут дубровачких зидина, вјечно траје, као што траје и на Дрини ћуприја. Закони не ограничавају ствараоца ни стварање, већ их усмјеравају и уздижу, уздижући тако оно божанско и стваралачко у човјеку. Граница није оков; човјек би већ на почетку сваког подухвата морао да се ограничи:

„Почетак и услов сваког делања је ограничење. Зато ниједна граница није оков, како се нама често чини, него прва црта вишег промисла, вишег стварања.“ 
Андрић сања и пише свој „Сан о Граду“ Дубровнику у Трсту, читајући Ива Војковића Машкарайе ucūog куйља и поново доживљавајући „оно пролетње преподне“ у Дубровнику, када му се Град отворио, и гледајући „у себи“ историју Града и Сан о Граду, поново се поклонивши „вјери, господству и слободи као најдостојнијим људским сновима“.

Андрићев „Сан о Граду“ објављен је у Јуїословенској юиви 1923. године, а окренут је прошлости - историји Града и његових зидина. Али „Сан о граду“ несумњиво је преважан за Андрићеву поетику и естетику, Тартаљи драг, значајан и вишесмјерно подстицајан поетско-есејистички запис. Тартаљски сан о Граду прати ауторе који су се на крилима маште храбро залијетали у будућност, вођени лепотом и сврсисходношћу градње и идејом о што људскијем и удобнијем животу човјека, будућег Београђанина.

Доиста, Тартаљине књиге дјелују на први поглед веома разнородно: какве везе има проучавање почетака историје опште књижевности код Срба са лекцијама из естетике Ђуре Даничића, односно са Андрићевом приповједачком естетиком и његовим, а са њим и истраживачевим, путем поред знакова, па са трагањем за пјесмама о пјесми, а поготову са утопијским маштањима о граду српских љекара, математичара и педагога XIX вијека, маштањима која и самога њиховога истраживача показују као маштара и сањара?

Једно је, међутим несумњиво: цјелокупно Тартаљино научно дјело има исти правац. Иво Тартаља се увијек бави крупним естетичким проблемима универзалног значења и домета и његово бављење естетиком је увијек не само из сусједства, већ из средишта поетике. У том погледу су нарочито рјечити наслов и поднаслов његове капиталне књиге Прийовеgачева есииеиика. 
Прилаз йроучаваюу Анgрићеве ӣоетиике. Слична ситуација је и када се бави пјесмама о пјесми, па и Даничићевим лекцијама из естетике, а поготову када пише о почецима проучавања опште књижевности код Срба.

„Најпроблематичнија“ је, изгледа, баш књига Беоїpag XXI вијека. Ту је највећма ријеч о футуролошким предвиђањима Београда и његове будућности из деветнаестога у двадесет првом стољећу; о утопијама и понекој антиутопији. А Београд, ипак, није земља Утопија Томаса Мора; није Нигрин који нигдје не постоји, већ - упркос пречестим разарањима и бомбардовањима бијели град међу градовима који привлачи громове, а ипак ниже стољећа. Ова Тартаљина књига јесте омаж Београду и похвала оним духовима који су радили на његовој изградњи и напретку; који су маштали и сањали о Београду у будућности. Зато је ово веома топла књига о своме граду; књига дубоке оданости Београду у најплеменитијем смислу ријечи. И књига захвалности оним озбиљним и великим духовима који су у деветнаестом вијеку мислили необично на овај град и његове становнике два вијека унапријед.

Све је то лијепо и племенито, али остаје питање какве везе те, претежно урбанистичке, утопије имају са питањима естетике и поетике. Наш одговор је на ово питање управо овај текст у цјелини и подсећање на поетски запис о Дубровнику - „Сан о Граду“: „није ли и тај Андрићев сан помало, урбанистичка утопија“. Дјелимичан одговор на ово питања дао је и аутор, Иво Тартаља, при крају свога уводног текста:

„Остваривост је утопија по дефиницији варљива, али многе су наизглед неоствариве визије бољег света биле варљиво утопијске. Тек дуже искуство може да одлучи којим је замислима место у историји утопија, а којима је у историји урбанизма, у историји правних 
и моралних норми или у историји науке и технике. Најзад, неки ће превратничким жаром писане и преписиване странице утописта, наћи своје место негде између бајке и сатире, заувек у свету поезије.“

Дакле, неке странице утопија ће - поновимо то „наћи своје место негде између бајке и сатире, заувек у царству поезије“. Али ни оне урбанистичког усмјерења нијесу, нити могу бити, сасвим изван естетског и естетике. Напротив, оне су привлачне управо са љепоте својих урбанистичких и архитектонских визија, али и са свога стила и израза. Љепота је често чак и предмет њихове расправе - љепота града и живота у њему. А да утопије налазе своје место између бајке и сатире можда најочигледније потврђује својим насловом, својом садржином и значењем Споменика роман Бајка Добрице Ћосића који Тартаља наводи у својој књизи.

Двадесети вијек је био вијек процвата, утопије и антиутопије. Социјалистичке револуције су прокламовале идеал једнакости и бескласног друштва, елиминацију експлоатације и јединство свијета преко уједињења пролетера свих земаља. Антиутопије су настајале на изневјереним идеалима, а на Западу из изгубљеног и отуђеног човјековог положаја у свијету. Човјек је контролисан, манипулисан и сведен на број, израбљиван и понижен. Тоталитарни системи, атомска бомба, свјетски ратови, сумња у срећу коју доноси технички напредак, биолошки ратови, роботизација човјека - све је то довело до снажног таласа антиутопије на планетарном нивоу. (Анти)утопијски роман је постао жанр у двадесетом стољећу, а понекад и врхунска дјела тога стољећа имају снажно наглашене антиутопијске особине. Такви

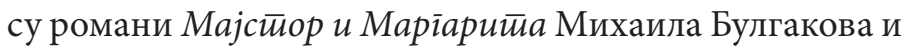
Чевеніуур Андреја Платонова. 
Претеча модереног (анти)утопијског романа је Херберт Велс са својим романом Машина Времена (1985), а слиједе га Јевгениј Замјатин са кратким романом $М$ и (1922), Олдос Хаксли са романом Врли нови

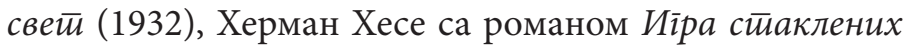
иерли (1943), па Џорџ Орвел са романима Животииғска барма (1945) и 1984. (1949) који су имали изванредну рецепцију на југословенском тлу.

Српски писци послије Другог свјетског рата доживљали су праву драму од преокрета из утопијског виђења револуције и социјализма у антиутопију. Бајции Добрице Ћосића припада право првјенства, али се ти преокрети виде чак и унутар исте књиге (Б. Ћопић, Башй съезове боје). Свакако је у овом жанру најимпозантнија антиутопијска трилогија Борислава Пекића (Беснило, $A \bar{u}-$ ланйuga и 1999.), али се цио његов опус може разумијети као велики антиутопијски систем у знаку мита о златном руну, односно човјековом првом погрешном кораку - о избору златног руна као универзалног идеала и цивилизацијског принципа. И Пекићев новелистички вијенац Нови Јерусалим - квинтесенција Пекићеве приповједачке прозе - носи снажан, чак романтичан печат антиутопије.

Тартаљина књига се, дакле, не бави неким споредним питањима, мање-више некњижевним, већ разматра једно од доминантних питања књижевности XX вијека - питање утопије и антиутопије - и то на грађи из XIX стољећа која је усмјерена на XXI вијек. У том погледу књига Ива Тартаље је изузетно актуелна и усмјерена на сржна питања. Она је, као и остале Тартаљине књиге, отпорна на промјене моде - једнако је жива данас као и прије тридесетак година.

У средишту пажње ове Тартаљине књиге су четири списа српских аутора. Ти списи су као прилози штампани на крају књиге, чиме се књига документује, а 
читаоцу се пружа могућност провјере и порећења.

Први је напис др Милана Јовановића, љекара и књижевника, професора хигијене и судске медицине на Великој школи - „Нове вароши - нов Београд“, и он је „претежно урбанистички“. Његова функција у овој књизи о раним домаћим утопијама је „да покаже историјско залеђе и да послужи за поређење“.

Јовановићев спис је одзив на књижицу Емилијана Јосимовића, професора математике и геометра, коме је била повјерена „израда плана регулације старог дела вароши оивиченог шанцем“ и прилагођавање оријенталне турске вароши „урбанизму европског типа“. Јосимовић је припремио „нацрт великог преуређења“ и 1867. године публиковао „објашњење тог нацрта“"као самосталну књижицу. Милан Јовановић подржава Јосимовићев пројекат допуњавајући га властитим мислима. Оба аутора виде будући Београд као велику раскрсницу копнених и водених саобраћајница и као један од најважнијих трговачких центара на истоку Европе.

Јовановић не подређује своје визионарство никаквој прагматици становања, већ је прва и основна идеја, и главни идеал, па и прва кључна ријеч у његовом спису - љепота:

„Лепота је прва реч у чланку Милана Јовановића о новим варошима; лепој је вароши овде посвећена прва и последња мисао. Београдски визионари су обузети жељом да се покаже чар пространих видика и да се погледу открије питомина околине. Градитељски подвизи оцењују се у исти чак са становишта благодати грађана и са становишта естетике, једно се од другог не разлучује. Мислило се да ће човекова рука природу само оплеменити. Кад је замишљано летење пут звезда, није то било да би се напустила опустошена планета.“ 
Управо из тих разлога љепоте, али и функционалности, односно усклађености с човјеком и људским потребама, Јовановић хвали Јосимовићева рјешења. у основи Јосимовићевих и Јовановићевих начела је увјерен је Тартаља - функиионалисииччка естиейика (подвукао Ј. Д.): „градови око којих је разапета мрежа водених и гвоздених путева и где је живот најбоље обезбеђен - уједно су и најлепши“.

Дакле - естетика, дакле - љепота која је у функцији љепшег и пријатног човјековог живота. Отуда и предлог да се град развија у ширину, да се између кућа остави довољно простора струјању ваздуха, сунцу и зеленилу; да су „за стамбени део вароши пожељне одвојене једноспратне и двоспратне куће са малим цветњацима који гледају на улицу и са повећим баштама у позадини“. Како то данас звучи људски, сувише људски. Јовановић препоручује заламање правих углова на кућама са раскрсница и стварање мноштва малих тргова, за шта је могао бити подстицајан Беч.

Заносе маште и грађења у машти Тартаља препознаје и у чланку „Београд“ чији је писац Милан Кујунџић Абердар, пјесник, суплент филозофије на Великој школи, који је Београду у будућности давао особине вилинског града:

„Куће ће се дизати као вилински двори, калдрма ће бити равна као мермер, осветљење ће бити као усред божјега дана, баште и забаве забављаће човека...“"

Неке идеје о Београду будућности могле су доћи као подстицај од живих примјера европских и америчких градова, али знатан дио „идеја из визионарског списа о будућем граду није имао седамдесетих година XIX века никакву подлогу на кугли Земаљској. Свет 
без оружја и ратова, без цензуре и бирократије, свет у којем се ради од забаве, а живи у изобиљу - могао се оцртавати само у жељама онаквих сањара какви се обично називају утопистима“.

Највише истраживачке пажње и простора у књизи Иво Тартаља је посветио анонимном спису „Београд после 200 година“, објављеном у Срйском омлаgинском каленgару за просту 1871. годину, потписаном звездицом, односно „пахуљицом“, и др Ђорђу Натошевићу, као потенцијалном аутору анонимног текста и његовим сродним радовима. Овај стил је, за Тартаљу, „делимично као испуњено предвиђање, делимично као класична утопија“. Управо услед густог преплитања, неостварених замисли са остваренима, Тартаљи овај спис изгледа фасцинантнији при крају двадесетога, па и првим деценијама двадесет и првог вијека, као што је то могао бити у доба свога настанка.

Анонимни спис подсјећа на класичне утопије, јер „назначује основне црте једног идеалног града“, па га Тартаља пореди с утопијским визијама градова, посебно оним насталим на просветитељским темељима. И у Београду будућности образовање је темељ преображаја и напретка, а Београђани имају на располагању мноштво библиотека, читаоница, музеја, научних кабинета и гаје поштовање према заслужним научницима и умјетницима. Природне силе и њихова енергија су у служби човјека, па помоћу њих људи обављају физичке послове за краће вријеме и могу да скрате радно вријеме, односно радни дан. Машине замјењују човјека, а неке контролишу чак и дресиране животиње. Жене квалитетно обављају бројне послове који су били у надлежности мушкараца. Љубав и разумијевање међу људима потиснули су вјерске расколе. Старе утопије су препознаване по неодрећености мјеста и времена; 
анонимни спис је све то прецизирао већ у наслову. Будући Београд није, као што је то понекад случај у утопијама, неко издвојено острво, већ је само средиште друштвеног, културног и трговачког живота - жива трговина и саобраћај битна су обиљежја будућега града. То је будући град слободе, са слободом штампе, без политичких и духовних силеџија, са високо развијеним школством и бригом школа на свим нивоима за развој талената, људских умних и физичких снага. Начело користи и утилитаризма, тако карактеристично за утопије, овдје је усклађено - и то изузетно важно - са начелом љепоте.

Видовита ријеч безименог писца своју љепоту и снагу налази у сродности с исконском снагом народних умотворина, а временом добија неодољиву чар удаљавањем од тренутка настанка и објављивања визије и приближавањем временске тачке која је својевремено у будућности замишљена као далека и обећавајућа. Двадесети вијек је понешто од понуђене визије надмашио, али је доста тога изневјерио, па то густо преплитање остварених и неостварених замисли чини овај спис за Тартаљу фасцинантнијим него у доба његовог настанка.

За нас је фасцинантно Тартаљино упорно и дисциплиновано, веома дуго и савршено методичко трагање за аутором анонимнога списа и доказивање ауторства. Несумњиво је да је аутор био високошколац, да је био даровит писац и посједовао различита, а нарочито медицинска знања, па су „првоосумњичени“ потенцијални аутори били књижевници-медицинари. Тартаља открива цио круг данас мање познатих или непознатих људи који су се озбиљно бавили овим питањима и свакоме од њих посвећује пажњу. Методом искључивања мање вјероватних аутора дошло се до два Милана Јовановића - „Морског“ и „Батута“ - и др 
Ђорђа Натошевића (1821-1887). Животни и списатељски путеви, а нарочито интересовања, Милана Јовановића Морског и Ђорђа Натошевића укрштали су се, па и подударали. Тартаљина истраживања показују да је Ђорђе Натошевић „неишчитани писац“ и највећи дио ове књиге је његово освјетљавање и ишчитавање. Тартаљина хипотеза је да је аутор анонимног списа „Београд после 200 година“ управо Ђорђе Натошевић и ту хипотезу развија и доказује.

Прво даје својеврсну књижевну биографију Ђорђа Натошевића, освјетљавајући га као припадник „естетике Вукова круга“ који се „залаже за оживљавање успомена на велике ликове из народне прошлости“ и за умјетност ослоњену на народну традицију. Отуда изразита склоност ка пословицама и њихово функционално коришћење у сопственим текстовима, као и језгровит пословички стил. Потом овог бечког студента и доктора медицине, Даничићевог и Вуковог познаника и пријатеља, налази у Новом Саду као љекара „бечког епископа и просветара“" владику Платона Атанацковића гдје другује са Богобојем Атанацковићем и гдје је оставио трага о свом поштовању жене и залагању за њена права, и тврдећи да од тога поштовања зависи ниво цивилизације. У Новом Саду је радио као директор гимназије и професор природних наука, а затим је постао школски савјетник за српске школе у Војводини 1857. године. Тих година је формулисао идеју да је „мислити - то је човек бити“, јер мишљење омогућава познавање себе и цијелога свијета, а посебно проницање у будућност. Његов утицај на велике духове овога времена био је веома снажан и недовољно широко познат, тако да је Милан Шевић оцијенио да је Натошевић „отац српске специфичне књижевности дечје“, будући да је „Змај почео писати за децу на његово наговарање“. 
Мјерећи степен оригиналности овога писца и мислиоца, Иво Тартаља упућује на Натошевићев спис

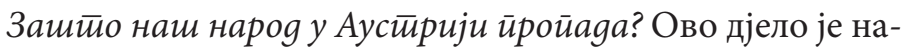
стало као одговор на анкету Матице српске за коју је 1865. расписала награду. Главни узрок пропадања народа он види у самим Србима, а не у другим народима који живе под приближно истим условима. Натошевић указује на растурена и запостављена имања, запостављен и неуредан породични и брачни живот, дивље бракове, занемарену дјецу, алкохол, побачаје, незнање сваке врсте, па на вјерску нетрпељивост, унутарњу завађеност и раздијељеност, сваковрсне расколе и сукобе. Неопходно је рационално суочење с реалношћу и већи ослонац за науку и образовање. Хаосу супротставља ред и строгост, одговорност најутицајнијих и најугледнијих људи попут свештеника и епископа, образовање насупрот „претераностима и лудостима“, пут мирних реформи насупрот побуне.

Натошевић напушта на горе измјењен положај просветног савјетника у Пешти и 1867. прелази у Србију за референта у Министарству просвете и црквених дела, са благонаклоношћу кнеза Михаила. Упркос пожртвованом и несебичном раду, морао је 1871. године напустити Београд због неразумног и неразумљивог отпуштања из службе. Само двије године послије веома горких искустава у Србији и Београду, Натошевић је највјероватније том истом граду посветио „најлепшу химну“. Ускоро је његов живот изненадно завршен: човјек који је вјеровао у дуг људски живот, који се за дуг човјеков живот залагао, умро је напрасно у својој 66-ој години.

У Натошевићевим списима нема ништа што би личило на утопију или визионарска предвиђања, али има низ мјеста која показују сличност ставова са ста- 
вовима анонимног написа о будућем Београду. Тартаља узима у свом доказном поступку за мото свакога од двадесет два потпоглавља кратак цитат из анонимне утопије о будућем Београду, па са тим цитатом пореди Натошевићеве ставове исказане у несумњивим Натошевићевим радовима. Показује се несумњива подударност тема и ставова, па Тартаља формулише и заокружује Натошевићеве погледе на: екологију, урбанизам, архитектуру, неговање здравља, макробиотичку исхрану, дуговјечност човјекову, раноранилачке навике, заштиту животиња, путеве и трговину, индустрију, машине-роботе, енергетику, удруживања, вјеру, живот у свемиру, управу, школу, учитеље, љубав, женидбу и удају, женска занимања, књиге и библиотеке, начела критике.

Послије оваквог систематичног истраживања и доказивања своје хипотезе о могућном ауторству анонимног утопијског списа „Београд после 200 година“, Тартаља опрезно закључује:

„Спис о Београду 2071. године јесте, по свему судећи, сасвим оригинално изведена синтеза дугих размишљања о могућностима бољег живота на овом тлу. У стваралаштву писца енциклопедијске ширине тај спис се издваја као језгро у којем се сажело духовно завештање целог једног немирног нараштаја.“

Већ у наслову поглавља о напису Стојана Новаковића - „Прогноза - или утопија? - Стојана Новаковића“ - Иво Тартаља поставља дилему да ли је Новаковићев текст „након сто година“ прогноза или утопија и процјењује да би се то, можда, могло знати крајем друге деценије XXI вијека. Судећи по садашњем стању ствари, бојати се да је визија хармоничног и заједничког живота на словенском југу, коју је прије 
једног стољећа понудио стари професор, остала само утопијска. Њени рушитељи су били много упорнији, досљеднији, неупоредиво бруталнији и безрезервно подржани од међународне заједнице у односу на градитеље. А није морало тако бити. Стојан Новаковић је видио зближавање и заједницу Јужних Словена као једини пут њиховог опстанка, иначе ће их прогутати магле историје и туђи, њима неупоредиво даљи, па и непријатељски народи.

Новаковић пише свој рад 1911. године, уочи Балканских ратова и Првог свјетског рата, када су Јужни Словени живјели расцјепкани и раздијељени између више земаља и двију тадашњих царевина велесила - Турске и Аустроугарске. Природно је што страхује за народни опстанак: стари дипломата је што знао, а што слутио какви су планови великих сила и какав је положај Србије, и свих Јужних Словена, у тим плановима. Зато је он превасходно усмјерен на политичка и културно-политичка, прије свих језичка и књижевна питања јединства Јужних Словена у будућности, док су његови погледи на урбанистички и технички напредак већ оцјењивани као скучени. Та су питања за њега, очевидно, била од секундарне важности и у њих је био мање упућен.

Тартаљи није промакла сличност Новаковићевог увода са уводом четрдесет година старијег анонимног чланка из Омлаgинскоі каленgара. Новаковић је морао тај чланак познавати, јер је био читалац, „сарадник, па и благонаклони критичар“ Омлаgинскоі каленgара. Новаковићев чланак је био у урбанистичком погледу неупоредиво „скученији“ од свога претходника, а „технолошка машта“ старога професора неупоредиво је скромнија од оне коју је развијао Никола Тесла у Америци.

Тесла је говорио о техничким открићима, о моћи електрицитета и чудима електротехнике, преносу 
енергије, чак и бежичном, могућностима контроле падавина и коришћења Сунчеве енергије, читању мисли на екрану; о писаћој машини коју ће покретати људски глас; о теледиригованим пројектима и роботима у виду авиона, балона, аутомобила, подморница све са вештачком интелигенцијом. Новаковић је, пак, био усмјерен на питања уједињења Јужних Словена као услова њиховог опстанка са Београдом као будућим центром.

Стојан Новаковић није био усамљен у својим погледима. Текст му је објављен у Хрвайскосрйском, односно Срйскохрвайском алманаху за 1911. годину, штампаном на оба писма, а овоме је 1910. године претходио Алманах хрвайских и срйских ӣјесника и иррииовеgача. Око ових алманаха равномерно се окупио велики број пјесника и приповједача, можда највећи број икада заједно окупљених српских и хрватских живих писаца.

У Алманаху за 1911. појавили су се и прилози доиста највећих научника. У уводном дијелу Стојан Новаковић је дао избор ставова Доситеја Обрадовића о јединству Срба и Хрвата. Ватрослав Јагић је објавио ћирилицом мемоарски текст о томе како је научио ћирилицу; затим је подсјетио на свој напис о историји књижевности Југословена на чешком језику гдје није правио разлику између Срба и Хрвата, па на своје ставове о Доситеју и Вуку, а на крају подвлачи и мјесто књижевности у уједињавању народа из свога

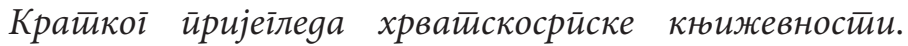
Знаменити слависта Матија Мурко написао је чланак „Јединство језика и књижевности Хрвата и Срба“, а Јован Цвијић је срочио програмско писмо уредништву о српскохрватском јединству. У уводном дијелу је штампан и Новаковићев прилог „Након сто година“ као визија перспективе јужнословенског јединства.

Новаковић је, као озбиљан историчар, веома држао до познавања прошлости, вјерујући да познавање 
прошлости даје пророчки поглед у будућност, а на јединство Јужних Словена гледао је као на процес који би за једно стољеће могао бити изведен, па и довршен. Новаковић је свој прилог замислио као биљешке једног Загрепчанина са кружног путовања по јужнословенским крајевима, укључујући Бугарску и Македонију. Средишњи део чланка је извештај о предавању професора Видовића у Велелепном Доситејевом дому као културном средишту будућности Београда. Доситеј је и у Алманаху био кључна личност око које су се Срби и Хрвати зближавали и уједињавали, па отуда и његов повлашћен дом у Београду у будућности, и Видовићево предавање у том дому.

Презиме Новаковићевог предавача је симболично: онај који види, добро и далеко, способан да сагледава и прошлост и будућност. Видовић излаже процес уједињавања Јужних Словена током XX вијека, описује средства којима је то уједињење извршено, посебно истичући значај и улогу књижевности у том процесу. Предавач одговара на примједбе из публике о угрожености локалних обиљежја културе као и о томе да ли су Срби и Хрвати један народ. Новаковићев предавач никако не занемарује посебности ни локална обиљежја, али бојати се да прецјењује јединство постигнуто међу интелектуалцима и интелектуалну елиту уопште, као што никако не занемарује разорну опасност туђих интереса и утицаја који су у основи антисловенски и непријатељски.

Несумњиво је да је стари професор и политичар дао своју визију уједињења и свој допринос уједињењу за које је вјеровао да је остварљиво и реално, а не само утопијско. Уједињење Јужних Словена замишљао је, очевидно, као миран, дуготрајан, еволутиван процес са много искушења и препрека. Тај процес би био законски и правно уређен и окончан као гаранција 
сигурности и опстанка, што би значило побједу над сепаратистичким и краткорочним циљевима, али и над малигним туђим утицајима. Бојати се да је прецјењивао и идеализовао интегративне, а потцјењивао сепаратне, а нарочито туђинске снаге, мада је њиховог присуства и сталне опасности био веома свјестан.

Београд XXI вијека је био виђен као средишњи интегративни град Јужних Словена.

Драматична збивања крајем XX вијека била су усмјерена на разарање сваке, па и Новаковићеве визије југословенског јединства. Програмирана атомизација словенскога свијета, којој смо свједоци, не даје разлога ни аргумената за оптимистично повјерење у ближу реализацију идеја Новаковићевог професора Видовића.

Урбане, урбанистичке, политичке и културнополитичке утопије које се тичу Београда и којима се бави Тартаљина књига из 1989. године имају и данас шта да кажу својим читаоцима и да постакну машту и прегнућа савременика на нове замисли, подухвате и доказе љубави према своме граду, а посебно су изазов бризи за будућност и љепоту тога града као националног, јужнословенског и европског свакодневног центра. Сан о граду подразумијева и одговорност за град, за његову прошлост, садашњост и будућност, и за његову љепоту, увијек.

Од изразитог су значаја Тартаљина наизглед мала, а истинска велика открића српских антиутопија, њиховог мјеста и значаја у контексту овога жанра и њиховога развоја. Зато ћемо им посветити посебан осврт. 